\title{
Effect of Environmental Heat Stress on Performance and Carcass Yield of Broiler Chicks
}

\author{
Adnan Yousaf ${ }^{1 *}$, Adnan Jabbar ${ }^{1}$, Nasir Rajput ${ }^{2}$, Azizullah Memon ${ }^{2}$, Rehana Shahnawaz ${ }^{3}$, Nasir Mukhtar ${ }^{4}$, Farhan Farooq ${ }^{4}$, \\ Muhammad Abbas ${ }^{5}$, and Rabia Khalil ${ }^{1}$ \\ ${ }^{I}$ Salman Poultry (Pvt) Limited, Rawalpindi, Pakistan \\ ${ }^{2}$ Department of Poultry Husbandry, Sindh Agriculture University Tandojam, Pakistan \\ ${ }^{3}$ Department of Veterinary Pharmacology, Sindh Agriculture University Tandojam, Pakistan \\ ${ }^{4}$ PMAS-Arid Agriculture University Rawalpindi, Pakistan \\ ${ }^{5}$ Faculty of Animal Husbnadry \& Veterinary Science, Sindh Agriculture University Tandojam, Pakistan \\ *Corresponding author`s Email: dr.adnan011@gmail.com
}

\begin{abstract}
Environmental heat stress is one of the most challenging conditions which have adverse effect on the poultry industry. Broiler chickens are sensitive to heat stress mainly due to not having sweat glands. The current study was conducted to observe the effect of heat stress on performance of Ross-308 broiler chickens. 1600 Ross-308 broiler day old chicks were obtained from local hatchery and randomly divided into two groups, the heat stress group A $(\mathrm{n}=800)$ and heat free group B $(\mathrm{n}=800)$. Group A was reared in high temperature $\left(101^{0} \mathrm{~F}\right)$ whereas group B was reared in ideal temperature. To evaluate the physiological stress indicators blood glucose levels and total blood cell count were checked on day 21 and 28. The parameters observed were; feed intake, body weight gain, feed conversion ratio, water intake and carcass yield. The results indicated that feed intake, weight gain, water intake, feed conversion ratio and carcass yield were significantly higher in group B compared to group A. It was concluded that heat stress has deleterious effect over the performance of broiler Ross-308 chicken.
\end{abstract}

Key words: Broiler Ross-308, Carcass yield, Environmental, Heat stress, Performance

\section{INTRODUCTION}

Poultry is the one of the fastest growing industry of the animal production (Yousaf et al., 2017). About 1.3 billion people are employed directly or indirectly on livestock industry and accounts for $40 \%$ of agriculture Gross Domestic Product (GDP) (Anonyms, 2011). In Pakistan it is the second largest industry, which play key role in GDP of country (Yousaf et al., 2017). Poultry products are rich source of protein and good source of income. Importance of poultry is further emphasized by its demand and production ability in the country (Hussain et al., 2015).

Heat stress is one of the most challenging environmental conditions which have adverse effect on poultry industry. Broiler chickens are sensitive to heat stress (Yousaf et al., 2019, Yousaf et al., 2018). Poultry birds do not have sweat glands for heat releasing factor, if panting failed to reduce the high internal body temperature, birds become inactive, exhausted and mortality occurred because of the circulatory, respiratory and electrolytes imbalance (Swayne, 2017). Heat stress induces hormonal changing's which increased corticoid secretion (Brown et al., 1973). It has been investigating the effect of high environmental temperature on the performance of different poultry species, including broilers (Dozier et al., 2007) and has found that high environmental temperatures have deleterious effects on productive performance. Poultry birds increase body temperature (Altan et al., 2000), water consumption (Arce-Menocal et al., 2009) and decrease the feed consumption due to higher ambient temperature (Dozier et al., 2007).

Temperature and humidity play a key role which is one of the most important environmental factors during poultry house (Lourens et al., 2005). Broilers expose to ambient temperature, increase the body temperature (Reddy, 2000) consequently released corticosterone into the blood circulation to help the metabolism (Arce-Menocal et al., 2009). This hormone might cause cell mediate and humoral immunity failure because of the changing's in the plasma concentrations of corticosteroids and Adrenocorticotropic Hormone (ACTH) affect the lymphoid tissues, reduce the mass of spleen, thymus and bursa (Havenstein et al., 2003). Heterophils are present in the blood, formed leukocytes in the bone marrow, which are phagocytic in nature and shield the body of the bird against harmful micro-organisms and leukocytes play a key role in keeping immunity higher (Hussain et al., 2018). Heat exposure release excessive glucocorticoids, cause dissolution of lymphocytes which may cause lymphopenia (Yousaf et al., 2018). However, more heterophils are release in the blood circulation but heir phagocytic and bactericidal activities may decrease (Dozier et al., 2007). Heat stress is thought to have deleterious effect on an organism through the production of free radicals and Reactive Oxygen Species 
(ROS) within the body (Bruskov et al., 2000). Free radicals and ROS are compound generated naturally within an organism during normal biological processes and are essential for several body processes, included immune function (Valko et al., 2007). Increased production of free radicals and ROS compounds can cause damage to the constituents of various biological tissues including lipids, proteins, and deoxyribose nucleic acid (Fang et al., 2000). This research was practiced to observe the effect of heat stress on performance of Ross-308 broiler chickens.

\section{MATERIALS AND METHODS}

\section{Ethical approval}

This experiment was performed according to all ethics and animal rights of Sindh Agriculture University Tandojam, Pakistan.

\section{Selection of breed/site}

This experiment was conducted during the year 2018 to determine the effect of heat stress on the performance of Ross-308 broiler chickens. To determine the effect of environmental stress $(n=1600)$, broiler chicks were purchase from commercial broiler hatchery.

\section{Group classification}

On the arrival of birds to poultry house all the chicks were divided into two experimental groups group A served as the control ( $\mathrm{n}=800$ chicks) and group B served as the heat stress ( $\mathrm{n}=800$ chicks).

\section{Environmental condition poultry house}

Group A, containing chicks were reared in high temperature $101^{0} \mathrm{~F}$ whereas group B chicks were reared on ideal temperature $95^{\circ} \mathrm{F}$ at control poultry house. All conditions were remaining same of both groups expect the temperature. High temperature was providing during whole experiment to the group A chick. Humidity and ventilation were remaining same as group A. Poultry house condition of both chicks' groups are as table 1.

\section{Housing management}

The house was completely cleaned, washed and sanitized using disinfect (formalin) before arrival of the day old chicks. It was painted with lime stone and dried for 24 hours. One $\mathrm{Ft}^{2} /$ bird floor space under deep litter housing system was provided to each and every chick in the house (Hussain et al., 2018). Continuous light was applied during the whole study. For ventilation viper touch (Big Dutchman, Holland) system was installed. Rice husk was used as litter at four-six inches' depth. Turning of litter practiced twice a day to minimize the gas production in the shed and maintained proper ventilation.

\section{Feeding}

At farm chicks were offered water and feed immediately. All the chicks were feed and watered ad libitum on proprietary broiler started and finisher diets. The chickens were fed with starter diets from one to 10 days (3010 Kcal $\mathrm{ME} / \mathrm{kg}, 22 \%$ crude protein), grower diets from 11 to $20 \mathrm{~d}$ (3175 Kcal ME/kg, 20\% crude protein) and finisher diets from 21 to $35 \mathrm{~d}$ of age $(3227 \mathrm{Kcal} \mathrm{ME} / \mathrm{kg}, 18 \%$ crude protein). Water and feed were supplied ad libitum. The diet was formulated according to the recommendations of the NRC using windows user-Friendly feed formulation software program. Intake of feed and water was taken daily, while body weight and total feed consumed was recorded on weekly basis. Carcass measurements were also taken at the end of study.

\section{Vaccination schedule at poultry house}

The vaccination schedule which was practiced during this experiment trial is mentioned in table 2.

\section{Live performance parameters}

At the end of each and every experimental week, all birds and feed residues were weighed to determine the live performance parameters such as, average feed intake, average body weight, daily weight gain and Feed Conversion Ratio (FCR).

\section{Physiological stress indicators}

To evaluate the heat stress in birds the blood glucose levels and Total Blood Cell Counts (TBCC) were used as measures (Walberg et al., 2001; Arruda et al., 2016).

Blood glucose levels. Blood glucose levels were checked for the both groups (A and B) on day 21 and 28 . Ten birds from each pen were randomly selected and collected two ml blood from each bird from brachial vein by using 
insulin syringe. Birds were kept for one hour of fasting in the morning time then blood collection procured was performed. Birds was handled very calmly to avoid any physical stress, then easily blood was collected within 30 seconds, then blood sample immediately poured collected blood sample in vecutainer contains an anti-clotting agent (EDTA) and label it. Collected blood store in low temperature $\left(4^{0} \mathrm{C}\right)$ and submitted it in laboratory for further analysis. Blood glucose was measure for individually and recorded it.

Total blood cell count. To analysis the TBCC total RBC's and WBC's were manually counted in a Neubauer chamber according to (Walberg et al., 2001) at 1/200 dilution. The correction factors for WBC's and RBC's were the number of counted cells multiplied by 50 and $10000 / \mathrm{mm}^{3}$ actively. Packed cell volume was determined using the microhematocrit technique, total blood protein by the refractometry method, and hemoglobin levels by the cyanmethemoglobin method. Wintrobe's indices, including Mean Cell Volume (MCV), mean corpuscular hemoglobin concentration, and mean corpuscular volume, were determined according to Jain (1993) and Pierson, (2000). Differential WBC's counts were performed on blood smear slides stained with hematoxylin-eosin hematological stain. Heterophils, lymphocytes, eosinophils, monocytes, and basophils were counted, and the heterophil to lymphocyte ratio (H:L) was calculated.

\section{Carcass yield and quality}

To find out the quality and carcass yield on 30th day chicks were remaining for fasting up to 8 hours, 10 birds per each and every pen were randomly selected and weight it on digital scale then euthanized the birds to analysis the carcass yield. Yield was calculated as carcass weight relative to final body weight. Carcass quality was determined as a function of the presence or absence of dermatitis (breast blisters), dermatoses (scratches), arthritis, and bruising. Femoral degeneration was scored (0-2 scale) by the visual evaluation of the proximal epiphysis of the femur of both legs, according to the method described by Almeida Paz (2008).

\section{Measurements of performance indicators}

All birds were weighed individually upon arrival. Thereafter, the birds of each group were individually weighed and the feed refusals of the group were recorded on the same day every week. Such recordings took place on days 7,14 , 21, 28 and 35 respectively. Feed refusals were weighed and average feed consumption together with feed consumption ratios were calculated for each group. Mortality in each group was also recorded at the before mentioned days.

\section{Statistical analyses}

The raw data was tabulated in Microsoft excel then analyzed in ne-way analysis of variance (ANOVA) with JMP, software 7.0 Version and significant differences were compared through Student's comparison test. Result were considered significant if $\mathrm{P}<0.05$.

\section{RESULTS}

During 35d trail period, mortality, feed intake, weight gain and FCR was recorded and results were presented in table 3 and weekly in table 4. Mortality was reduced significantly $(\mathrm{P}<0.05)$ in control $\mathrm{B}(3.46 \pm 0.03)$ as compare to A (7.25 \pm 0.05$)$ group. Weight gain $(\mathrm{g} / \mathrm{bird})$ was significantly better $(\mathrm{P}<0.05)$ in $\mathrm{B}(2026 \pm 150)$ then A $(1780 \pm 176)$. FCR was found significantly better $(\mathrm{P} \leq 0.05)$ in $\mathrm{B}(1.3 \pm 0.05)$, than A group (1.75 \pm 0.05$)$. However, feed intake (g/bird) was also recorded better $(\mathrm{P} \leq 0.05)$ for group B $(2745 \pm 86)$, then A $(3121 \pm 76)$ the reason behind this due to heat stress decreased efficiency of feed utilization with increased environmental temperatures. The water intake (ml/bird) was significantly $(\mathrm{P}<0.05)$ higher in group A $(8105 \pm 87)$ and lowest for group B $(97399 \pm 65)$, table 3 and weekly presented in table 4.

\section{DISCUSSION}

The experimental model used in this research to study effect of environmental heat stress upon the performance of broiler. Interestingly, the effect of heat stress on broilers performance recorded a record variation in term of results. A portion of the negative effects seen during hyperthermia may be related to the increased production of free radicals and ROS (Abdel-azeem et al., 2015). ROS are known to have deleterious effects on the constituents of biological tissues (protein, amino acids, lipids, and DNA), leading to cell damage and ultimately death (Tong et al., 2013). ROS production linked to heat stress has been reportedly associated with poor performance in broiler chickens (Abdel-azeem et al., 2015). High ambient temperature and relative humidity are major environmental stressors that influence performance of broilers by reducing feed intake, feed efficiency, nutrient utilization and feed conversion ratio (Jabbar and Yousaf, 2017). While the ideal environmental temperature enhanced growth rate and feed consumption (Tong et al., 2013). As the result shows that the control group A of Ross-308 was high meat yield then heat stress group B due to ideal temperature. The obtained result of present study revealed that heat free group intake lower feed resultantly consumed lowered level of 
water, while ambient temperature caused painting in birds which was observed during this research trial and previous studies resulted painting when body temperature observed higher in the heat stress exposure birds, heat stress consequently increased body temperature, while broilers maintain their body temperature by increasing water consumption.

\section{CONCLUSION}

From the present study, it is concluded that under tropical climatic conditions, especially in Pakistan, heat stresscondition impact harmfully and adversely on the productivity of Ross-308 broiler chicken.

\section{DECLARATIONS}

\section{Author's contribution}

Dr. Adnan Yousaf and Dr. Adnan Jabbar was the main researcher of this article, Dr. Nasir Rajput was research coordinator, Dr. Azizullah Memon was research supervisor, Dr. Rehana Shahnawaz and Dr. Farhan Farooq revised the article, Dr. Nasir Mukhtar contributions in statistics, Dr. Muhammad Abbas and Dr. Rabia Khalil assisted in results analysis and other activities related to the research.

\section{Competing interests}

The authors have declared that no competing interest exists.

\section{Consent to publish}

The author(s) grant(s) the publisher the sole and exclusive license of the full copyright in the contribution. Consequently, the publisher shall have the exclusive right throughout the world to publish and sell the contribution in all languages, in whole or in part, including, without limitation, any abridgement and substantial part thereof, in book form and in any other form including, without limitation, mechanical, digital, electronic and visual reproduction, electronic storage and retrieval systems, including internet and intranet delivery and all other forms of electronic publication now known or here in after invented.

\section{REFERENCES}

Abdel-azeem A, Shamma TA and Omara O (2015). Seasonal variation and performance evaluation of broiler breeder chickens reared in enclosed houses. Egyptian poultry science journal, 35(4): 833-856.

Anonymous (2011). Food and Agriculture Organization of the United Nations. FAOSTAT. http://www.fao.org/news/archive/news-bydate/2011/en/

Almeida Paz ICL (2008). Problemaslocomotores e tecnicas de mensuracao. Anais da ConferenciaApinco deCiencia e Tecnologia Avicolas; Santos, Sao Paulo. Brasil. Pp.128-137. DOI: 10.1590/S1516-635X2010000300008

Altan O, Altan A, Oguz I, Pabuccuoglu A and Konyalioglu S (2000). Effects of heat stress on growth, some bloodvariables and lipid oxidation in broilers exposed to high temperature at an early age. British Poultry Science, 41(4):489-93. DOI: $10.1080 / 713654965$.

Arce-Menocal J, E Avila-Gonzalez, C Lopez-Coello, L Garibay Torres, and LA Martinez- Lemus (2009). Body weight, feedparticlesize, and ascites incidence revisited. Journal of Applied Poultry Research, 18:465-471. DOI:https://doi.org/10.3382/japr.2008-00095.

Arruda JNT, Mendes AS, Guirro ECBP, Schneider M, Sikorski RR, Sausen L, Dias ER and Bonamigo DV (2016). Live performance, carcass yield, and welfare of broilers of different genetic strains reared at different housing densities. Brazilian Journal of Poultry Science, 18: 141-152 DOI: 10.1590/18069061-2015-0092

Brown KI and Nestor KE (1973). Some physiological responses of turkeys selected for high and low adrenalresponse to cold stress. Poultry Science, 52(5):1948-54. DOI: $\underline{10.3382 / \mathrm{ps} .0521948}$

Bruskov VI, Malakhova LV, Masalimov ZK and Chernikov AV (2002). Heat-induced formation of reactive oxygenspecies and 8 oxoguanine, a biomarker of damage to DNA. Nucleic acids research, 30(6):1354-63. PMID:11884633

Dozier WA III, J Purswell, MT Kidd, A Corzo and SL Branton (2007). Apparent metabolizable energyneeds of broilers from 2.0 to $4.0 \mathrm{~kg}$ as influenced by ambient temperature. Journal of Applied. Poultry Research, 16:206-218. DOI: 10.3382/ps.2010-01132

Fang Y-Z, Yang $\mathrm{S}$ and $\mathrm{Wu} G$ (2002). Free radicals, antioxidants, and nutrition. Nutrition, 18(10):872-9. DOI:http://dx.doi.org/10.1016/S0899-9007(02)00916-4.

Havenstein GB, PR Ferket, and MA Qureshi (2003). Carcass composition and yield of 1957 versus2001 broilers when fed representative 1957 and 2001 broiler diets. Poultry Science, 82:1509-1518. DOI: $\underline{10.1093 / \mathrm{ps} / 82.10 .1509}$

Hussain A, Yousaf A, Mushtaq A and Rais M (2018). Prevalence of mycoplasma gallisepticum in ross-308 broiler breeder through the contrast of serological assessments in Pakistan. Journal of Dairy Veterinary and Animal Research, 7(1): 00185. DOI:10.15406/jdvar.2018.07.00185

Hussain J, Rabbani I, Aslam S and Ahmad HA (2015). An overview of poultry industry in Pakistan. World Poultry Science Journal, 71(4): 689-700. DOI:10.1017/S0043933915002366 
Jabbar A and Yousaf A (2017). Effect of age wise incubation programme on broiler breeder hatchability and post hatch performance. Online Journal of Animal Feed and Research, 7(1): 13-17.

Jain NC (1993). Essentials of Veterinary Hematology. Lea and Febiger, Philadelphia, 76-250. DOI: 10.1093/ps/84.6.914

Lea, Febiger Lourens A, H van den Brand, R Meijerhof and B Kemp (2005). Effect of egg shell temperature during incubation on embryo development, hatchability, and posthatch development. Poultry Science, 84:914-920. DOI: 10.1093/ps/84.6.914

Pierson FW (2000). Laboratory techniques for avian hematology. In: Feldman BF, Zinkl JG, Jain NC. Schalm'sveterinary hematology. 5th edition. Philadelphia: Lippincott Williams and Wilkins, 1145-1146.

Reddy C (2000). Features Maintaining Growth and Production-Overcoming heat stress. Poultry International, 39(2):36-41.

Swayne, HJ Barnes, JR Glisson and AM Fadly LMaDS (2017). Disease of Poultry. 13th. Press, ABlackwellPublishing Co Ames, Iowa Thigpen. Page 1056-1057.

Steinfeld H, Gerber P, Wassenaar T, Castel V, Rosales M and De Haan C (2006). Livestock's LongShadow: Environmental issues and options. Chapter 2. Rome: Food and Agriculture Organization ofthe United Nations, pp. 156-159.

Tong Q, Romanini C and Exadaktylos V (2013). Embryonic development and the physiologicalfactors that coordinate hatching in domestic chickens. Poultry Science, 92: 620-628. DOI: https://doi.org/10.3382/ps.2012-02509.

Valko M, Leibfritz D, Moncol J, Cronin MT, Mazur M and Telser J (2007). Free radicals and antioxidants in normalphysiological functions and human disease. The international Journal of biochemistry and cell biology, 39(1):44-84. DOI: https://doi.org/10.1016/j.biocel.2006.07.001

Walberg J (2001). White blood cell counting techniques in birds. Avian and Exotic Pet Medicine, 10(2): 72-76. DOI: https://doi.org/10.1053/saep.2001.22051

Yousaf A, Jabbar A and Ditta YA (2017). Effect of pre-warming on broiler breeder eggs hatchability and post-hatch performance. Journal of Animal Health and Production, 5(1): 1-4. DOI: 10.14737/journal.jahp/2017/5.1.1.4

Yousaf A, Shahnawaz R, Jamil T and Mushtaq A (2018). Prevalence of coccidiosis in different broiler poultry farms in Potohar region (distract Rawalpindi) of Punjab- Pakistan. Journal of Dairy Veterinary Animals Research, 7(3):87-90. DOI:10.15406/jdvar.2018.07.00196

Yousaf A, Tabasam MS, Memon A, Rajput N, Shahnawaz R, Rajpar S, Jamil T, Mushtaq M (2019) Prevalence of ascaridia galli in different broiler poultry farms of potohar region of rawalpindi-pakistan. Journal of Dairy Veterinary Animals Research, 8(1):71-73. DOI: 10.15406/jdvar.2019.08.00245 